\title{
Intellectual capital: Evidence from banking industry
}

\author{
Somayeh Boostani ${ }^{\mathrm{a}}$, Shabnam Fotovvat ${ }^{\mathrm{b}^{*}}$ and Karam Safari ${ }^{\mathrm{b}}$
}

${ }^{a}$ Masters in Financial Management, University of Abhar, Abhar, Iran

${ }^{b}$ Department of Management, University of Tehran Aras International Campus, Tehran, Iran

\section{H R O N I C L E}

Article history:

Received March 202014

Accepted 28 July 2014

Available online

August 32014

Keywords:

Human capital

Structural capital

Intellectual capital

Salmas

\section{A B S T R A C T}

This paper investigates different components on intellectual capital including human capital, structural capital and customer capital in banking industry in city of Salmas, Iran. The study uses the questionnaire developed by Bontis (1998) [Bontis, N. (1998). Intellectual capital: an exploratory study that develops measures and models. Management Decision, 36(2), 63-76.] to measure the effects of human capital. The questionnaire consists of 42 questions and all of them are designed in Likert scale. Cronbach alphas for human capital, structural capital and relationship capital were calculated as $0.79,0.76$ and 0.72 , respectively. The implementation of Kolmogorov-Smirnov test has indicated that the data were normally distributed. Using t-student test, the study determined that while management team did not pay enough attention on human capital, there were some statistically significant evidence that social and relationship capitals gained good attention.

\section{Introduction}

Human capital has been stated as the most important assets for most organizations and there are various studies associated with the impact of human capital on the performance of organizations (Córcoles \& Ponce, 2013; Mehralian et al., 2013). There are also many studies to develop various methods for measuring intellectual capital (Gogan \& Draghici, 2013). Boujelbene and Affes (2013), for example, studied the effect of intellectual capital disclosure on cost of equity capital for a case study of French companies. They empirically investigated the impact of intellectual capital disclosure (IC) on cost of Equity capital on firms listed in the French SBF 120 stock market index. They suggested the existence of a substantial and negative relationship between intellectual capital disclosure with its components of human capital, structural and the cost of equity. However, the negative impact of the relational capital disclosure was not validated. The understanding of the impact of IC disclosure on cost of equity capital helps policy makers in the evaluation of the expenses and advantages of disclosure. Sydler et al. (2013) executed a survey on relationship between intellectual capital and profitability of some firms and reported that IC was associated with a higher 
return on assets. Ho and Williams (2003) used a study on international comparative analysis on relationship between board structure and the efficiency of value added by a company from its physical capital and IC resources. A firm with good IC could be more productive in terms utilizing the resources (Chen et al., 2014). Lu et al. (2014) performed a study on the relationship between IC and performance in the Chinese life insurance industry. A company with good IC is believed to have better chance for customer retention (Longo \& Mura, 2011) and it can contribute substantially on setting up appropriate strategies (Rexhepi et al., 2013).

\section{The proposed study}

This paper investigates different components on intellectual capital including human capital, structural capital and customer capital in banking industry in city of Salmas, Iran. The study uses the questionnaire developed by Bontis (1998) to measure the effects of human capital. The questionnaire consists of 42 questions and all of them were designed in Likert scale. Cronbach alphas for human capital, structural capital and relationship capital were calculated as $0.79,0.76$ and 0.72 , respectively. The implementation of Kolmogorov-Smirnov test has indicated that the data were normally distributed. Table 1 summarizes the results of our findings.

\section{Table 1}

The summary of Kolmogorov-Smirnov test

\begin{tabular}{llccc}
\hline \multirow{2}{*}{ Number } & & Relational capital & Structural capital & Human capital \\
\cline { 3 - 5 } Normal Parameters & (Mean) & 35 & 35 & 35 \\
& .Std) & 2.89 & 2.92 & 3.1 \\
& & 0.48 & 0.46 & 0.46 \\
\hline \multirow{2}{*}{ Most Extreme } & (Positive) & 0.066 & 0.74 & 0.079 \\
Differences & & 0.066 & 0.059 & 0.048 \\
& & -0.05 & -0.068 & -0.079 \\
\hline Kolmogorov-Smirnov ) & & 0.681 & 0.785 & 0.874 \\
(Asymp. Sig. (2-tailed)) & & 0.742 & 0.569 & 0.43 \\
\hline
\end{tabular}

The proposed study of this paper considers the following three hypotheses

1. Human capital is within acceptable level in bank Melli Iran in city of Salmas.

2. Structural capital is within acceptable level in bank Melli Iran in city of Salmas.

3. Communication capital is within acceptable level in bank Melli Iran in city of Salmas.

In our survey, the population of the survey includes 35 full time employees who worked for Bank Melli Iran in city of Salmas, Iran. Since there were limited number of people working for this organization we have decided to distribute the survey among all employees. The study uses t-student test to verify various hypotheses of the survey.

\section{The results}

In this section, we present details of our findings on testing three hypotheses of the survey.

\subsection{The first hypothesis: The status of human capital}

The first hypothesis of the survey investigates the status of human capital. Table 2 demonstrates the results of the implementation of t-student.

Table 2

The summary of t-student test for measuring the effect of human capital

\begin{tabular}{lcccc}
\hline Variable & t-value & df & Sig. & Mean difference \\
\hline Human capital & -1.78 & 35 & 0.078 & -0.126 \\
\hline
\end{tabular}


As we can observe from the results of Table 2, human capital is not statistically significant and we cannot confirm the first hypothesis of the survey.

\subsection{The second hypothesis: The status of structural capital}

The second hypothesis of the survey studies the status of structural capital. Table 3 summarizes the results of the implementation of t-student.

Table 3

The summary of t-student test for measuring the effect of structural capital

\begin{tabular}{lcccc}
\hline Variable & t-value & df & Sig. & Mean difference \\
\hline Structural capital & -2.167 & 35 & 0.032 & -0.100 \\
\hline
\end{tabular}

As we can see from the results of Table 3, structural capital is statistically significant and we may therefore confirm the second hypothesis of the survey.

\subsection{The third hypothesis: The status of relationship capital}

Finally, the last hypothesis of the survey surveys the status of relationship capital. Table 4 presents the results of the implementation of t-student.

\section{Table 4}

The summary of t-student test for measuring the effect of relationship capital

\begin{tabular}{lcccc}
\hline Variable & t-value & df & Sig. & Mean difference \\
\hline Relationship capital & 2.795 & 35 & 0.006 & 0.140 \\
\hline
\end{tabular}

As we can find out from the results of Table 4, relationship capital is statistically significant and we may therefore confirm the last hypothesis of the survey.

\section{Conclusion}

In this paper, we have presented a survey to measure the present status of intellectual human in banking industry in city of Salmas, Iran. The study has implemented some parametric to test to verify the status of IC components including human capital, structural capital and relationship capital. Using t-student test, the study determined that while management team did not pay enough attention on human capital, there were some statistically significant evidence that social and relationship capitals gained good attention. The results of our survey are consistent with similar findings reported by Bani et al. (2014).

\section{Acknowledgement}

The author would like to thank the anonymous referees for constructive comments on earlier version of this paper.

\section{References}

Bani, M., Bani, A., Pourbagher, M. Taghavi, M., \& Mansourian, M. (2014). Measuring the relationship between equity and intellectual capital. Management Science Letters, 4, 739-742.

Bontis, N. (1998). Intellectual capital: an exploratory study that develops measures and models. Management Decision, 36(2), 63-76.

Boujelbene, M.A., \& Affes, H. (2013). The impact of intellectual capital disclosure on cost of equity capital: A case of French firms. Journal of Economics Finance and Administrative Science, 18(34), 45-53.

Chen, F.C., Liu, Z.J., \& Kweh, Q.L. (2014). Intellectual capital and productivity of Malaysian general insurers. Economic Modelling, 36, 413-420 
Córcoles, Y.R., Ponce, Á. T. (2013). Cost-benefit analysis of intellectual capital disclosure: University stakeholders' view. Revista de Contabilidad, 16(2), 106-117

Edvinsson, L., \& Malone, M. S. (1997). Intellectual Capital: Realizing Your Company's True Value by Finding Its Hidden Brainpower.

Gogan, L.M., \& Draghici, A. (2013). A model to evaluate the intellectual capital. Procedia Technology, 9, 867-875.

Ho, C.A.m, \& Williams, S.M. (2003). International comparative analysis of the association between board structure and the efficiency of value added by a firm from its physical capital and intellectual capital resources. The International Journal of Accounting, 38(4), 465-491

Longo, M., \& Mura, M. (2011). The effect of intellectual capital on employees' satisfaction and retention. Information \& Management, 48(7), 278-287

Lu, W.M., Wang, W.K., \& Kweh, Q.L. (2014). Intellectual capital and performance in the Chinese life insurance industry. Omega, 42(1), 65-74.

Mehralian, G., Rasekh, H.R., Akhavan, P., \& Rajabzadeh Ghatari, A. (2013). Prioritization of intellectual capital indicators in knowledge-based industries: Evidence from pharmaceutical industry. International Journal of Information Management, 33(1), 209-216

Rexhepi, G., Ibraimi, S. \& Veseli, N. (2013). Role of intellectual capital in creating enterprise strategy. Procedia - Social and Behavioral Sciences, 75, 44-51

Roos, G., Dragonetti, N. C., \& Edvinsson, L. (1997). Intellectual capital. J. Roos (Ed.). Macmillan.

Stewart, T., \& Ruckdeschel, C. (1998). Intellectual capital: The new wealth of organizations.

Sydler, R., Haefliger, S., \& Pruksa, R. (2014). Measuring intellectual capital with financial figures: Can we predict firm profitability?. European Management Journal, 32(2), 244-259. 